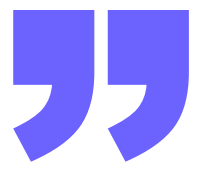

\title{
TYPES OF DEIXIS IN THE SONG LYRICS OF ARIANA GRANDE'S THANK U, NEXT ALBUM
}

\author{
Ni Made Savitri Dewi'1, I Wayan Resen², I Dewa Ayu Devi \\ Maharani Santika ${ }^{3}$ \\ Mahasaraswati Denpasar University, Indonesia ${ }^{123}$ \\ tiwiyantii@gmail.com¹@gmail.com, devimaharani17@gmail.com
}

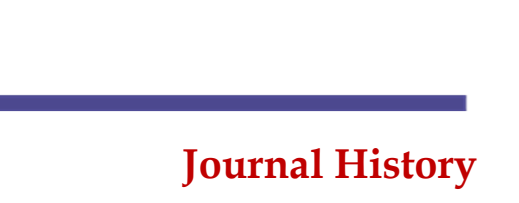

Submitted 24 $4^{\text {th }}$ December 2021

Revised 22nd January 2022

Accepted 23rd January 2022

Published 24 th January 2022

Keywords:

Deixis, type, album, song, lyrics

\begin{abstract}
This research entitled "Type of Deixis in The Song Lyrics of Ariana Grande's thank u, next Album". Deixis is an expression in language that in used to point who to person deixis, where to place deixis, and when to time deixis. The objective in this research is to find out and identify types of deixis in the song lyrics of Ariana Grande's thank u, next Album. Documentation method is used in collecting the data using listening, reading and note taking techniques. Qualitative method is used to analyze the data by using descriptive language for explaining the data. The result of this research shows that all types of deixis are found in the song lyrics of Ariana Grande's thank $u$, next album which include person deixis, spatial deixis, temporal deixis, social deixis and discourse deixis. This research found the occurrences of 550 person deixis (81\%), 109 temporal deixis (9\%), 7 discourse deixis (1\%), 32 spatial deixis $(7 \%)$, and 19 social deixis $(9 \%)$.
\end{abstract}




\section{INTRODUCTION}

Language can be defined as a means of communication for human. In daily life, people need language to communicate with each other and to interact to get information from other people. Also, language can be used to express about human feeling or emotion, their idea, thought, and imagination. It can be spoken or written. Spoken language is a form of language that is orally expressed using spoken words and usually followed by tone and body language.

Pragmatics is a study of the use of linguistic signs, words, and sentence, in actual situation. Based on Levinson (1983: 9), pragmatics is the study that learns about the language and context. According to Leech (1983: 6), namely pragmatics involves problem solving from the speaker's point of view, how to produce an utterance which will make the intended use. Moreover, Pragmatics is the study that learns about the situations of how language is used as determined by the context of society. In a simple way, pragmatics is the study that learns about speaker utterances that depend on the context. In pragmatics, there are many topics under issue, and one of them under study here is deixis.

Based on Yule (1996), Deixis is suite basic in technical terms of utterances. Cruse (2000:319) also states that deixis allows different perspectives to different people. Deixis is usually directly concerned with the relationship between the language and the context that is related to the structures of language (Levinson, 1983:55). Deixis is used to analyze the conversation, utterance or sentence, because every utterance in related to point about people, place or time like I, later, now. The meaning of the utterance in language will become clear if the listener know about who, where, and when the utterance uttered.

This study used three thesis reviewed a related literature, namely that by Debi Ratna Wati (2014) entitled A Deixis Analysis of Song Lyrics in Taylor Swift "RED" Album, that by Nurjanah(2018) entitled "A Deixis Analysis of Moana Movie Script", and that by Febby Tirza (2018) entitled "Deixis Interpretation on Donald Trump's Speech".

The researcher is interested to analyze song lyrics because music is favorite thing for many people especially for teenager, and the researcher used thank $u$, next album by Ariana Grande as a data source in this study because deixis can be found in its varieties in song lyrics. thank $u$, next album by Ariana Grande. There are all kinds of deixis in the song lyrics under study including person deixis, spatial deixis, temporal deixis, social deixis and discourse deixis.

\section{METHODS}

This research used Ariana Grande's album entitled thank $u$, next. In this album, consist of twelve English songs entitled imagine, needy, NASA, bloodline, fake smile, bad idea, make up, ghostin, in my head, 7 
rings, thank $u$, next, break up with your girlfriend, i'm bored. This album was released on 8th February 2019. Grande began working on this album in October 2018. This album has been sold 360.000 copies in its first week, and this album is the best sales of her career. The album was preceded by two singles, the title "thank $u$, next" and "7 Rings", both of which debuted atop the United States Billboard Hot 100 chart, becoming Grande's first two number-one songs in the US. "Break Up with Your Girlfriend, I'm Bored" succeed the third single on the day and peaking at number two on the Hot 100. All song in this album entered the Hot 100. This album was certified double platinum by the Recording Industry Association of America, and landed at number two on the US Billboard 200 Year-End chart of 2019. Globally, it was the eighth best-selling album of 2019, and fourth best-selling album by a female artist.

Documentation method is used in this study for collecting the data. In collecting the data, there are three steps as follows: first, listening to the song lyrics of Ariana Grande's thank $u$, next Album to get better understanding. Second, reading the song lyrics to determine which song lyrics of Ariana Grande's thank $u$, next Album can provide deixis. Third, classifying and note taking the song lyrics that contain deixis based on theory of deictic type by Cruse (2000: 2006). Qualitative method is used in analyzing the data in this study. In analyzing the data, there are two steps that were taken, as follows: first, analyzing the person deixis in the song lyrics of Ariana Grande's thank $u$, next Album based on theory of deictic types by Cruse (2000: 2006).

\section{RESULTS}

\section{RESULTS AND DISCUSSION}

The results of this study show that in twelve songs person deixis occur, in ten songs spatial deixis occur, in twelve songs temporal deixis occur, in eight songs social deixis occur and discourse deixis occurs. The percentage of data and the detailed description are presented below.

Table 1. Types of Deixis Found

\begin{tabular}{|c|c|c|c|c|c|}
\hline No & Types of Deixis & Classifications & Data & Total Data & Percentage \\
\hline \multirow[t]{3}{*}{1} & \multirow[t]{3}{*}{ Person Deixis } & First Person & 307 & \multirow[t]{3}{*}{550} & \multirow[t]{3}{*}{$81 \%$} \\
\hline & & Second Person & 137 & & \\
\hline & & Third Person & 106 & & \\
\hline \multirow[t]{3}{*}{2} & \multirow[t]{3}{*}{ Spatial Deixis } & Proximal Term & 9 & \multirow[t]{3}{*}{32} & \multirow[t]{3}{*}{$7 \%$} \\
\hline & & Distal Term & 10 & & \\
\hline & & Spesific Location & 13 & & \\
\hline 3 & Temporal Deixis & $\begin{array}{ll}\text { Pure } & \text { Deictic } \\
\text { Word/ } & \end{array}$ & 21 & 109 & $9 \%$ \\
\hline
\end{tabular}




\begin{tabular}{r|llccc} 
& \multicolumn{4}{|c}{ Specific Time } & \\
\cline { 3 - 4 } & & Verb Tense & 88 & \\
\hline $\mathbf{4}$ & Social Deixis & Social & 19 & 19 & $2 \%$ \\
\hline $\mathbf{5}$ & Discourse Deixis & Discourse & 7 & 7 & $1 \%$ \\
\hline \multicolumn{2}{r}{ TOTAL } & & $\mathbf{7 1 7}$ & $\mathbf{1 0 0 \%}$
\end{tabular}

There are five types of deixis identified and gathered from the songs, which are person deixis, spatial deixis, temporal deixis, social deixis and discourse deixis as presented in the table above. The most frequently found among all types of deixis is person deixis, since this album is about the personal love story of the singer or song writer. This makes a lot of person deixis used by the singer or song writer to refer to herself. There are 550 person deixis identified with a percentage of $81 \%, 109$ temporal deixis data with a percentage of $9 \%, 7$ discourse deixis data with a percentage of $1 \%$, 32 spatial deixis data with a percentage of $7 \%$ percent and 19 social deixis data with a percentage of $2 \%$. Based on the data above, the total of the deictic words which found in Ariana Grande's thank $u$, next Album was 717.

\section{DISCUSSION}

\subsection{Person Deixis}

The person deixis described by Cruse (2000:319) is an expression that is used to point to person and it is in the form of pronouns. The person who makes the utterance or sentence uses to person deixis to refers to herself. Person deixis is divided into three terms, such as the speaker (first person), the addressee or the person(s) to whom it is spoken (second person) and the person or persons to whom it is not spoken (third person).

Person deixis includes pronouns such as (I, mine, you, yours, hers, him, herself, herself, myself), possessive adjectives (my, her, your), and verb inflection (you love, I love, he or she loves).

Table 2. Person Deixis in Twelve Songs of Ariana Grande's thank u, next Album

\begin{tabular}{l|llll}
\multirow{2}{*}{ No } & \multicolumn{1}{c}{ Song Title } & \multicolumn{3}{c}{ Person Dexis } \\
\cline { 3 - 4 } & & First Person & Second Person & Third Person \\
\hline $\mathbf{1}$ & Imagine & $\begin{array}{l}\text { I, Me, My, We, } \\
\text { Us }\end{array}$ & You, Your & It \\
\hline 2 & Needy & I, Me, My & You, Your & It \\
\hline 3 & NASA & I, Me, My & You, Your & It, Them, She \\
\hline 4 & Bloodline & I, Me, My, We, You, Your & It, They
\end{tabular}




\begin{tabular}{|c|c|c|c|c|}
\hline & & Mine & & \\
\hline 5 & fake smile & $\mathrm{I}, \mathrm{Me}, \mathrm{My}$ & - & It, They, Them \\
\hline 6 & bad idea & I, Me, We, Mine & You & It, Him, He \\
\hline 7 & make up & $\begin{array}{l}\mathrm{I}, \mathrm{Me}, \mathrm{My}, \mathrm{We}, \\
\text { Mine }\end{array}$ & You & It, He \\
\hline 8 & Ghostin & $\mathrm{I}, \mathrm{Me}, \mathrm{My}, \mathrm{We}$ & You, Your & It, $\mathrm{Him}, \mathrm{He}$ \\
\hline 9 & in my head & $\mathrm{I}, \mathrm{Me}, \mathrm{My}, \mathrm{We}$ & You, Your & It, They \\
\hline 10 & 7 rings & $\mathrm{I}, \mathrm{Me}, \mathrm{My}, \mathrm{We}$ & You & $\begin{array}{l}\text { It, They, Them, } \\
\text { His, Hers }\end{array}$ \\
\hline 11 & thank $u$, next & $\mathrm{I}, \mathrm{Me}, \mathrm{My}$ & You & She, He, Her \\
\hline 12 & $\begin{array}{l}\text { break up with } \\
\text { your } \\
\text { girlfriend, } \\
\text { bored }\end{array}$ & $\mathrm{I}, \mathrm{Me}, \mathrm{My}, \mathrm{We}$ & $\begin{array}{l}\text { You, } \\
\text { Yours }\end{array}$ & It, She \\
\hline
\end{tabular}

From the table above, it could be seen that the three forms of person deixis occur in all song lyrics of Maroon 5's in ten (12) songs of the thank $u$, next album. This study found five hundred and fifty (550) deictic terms belonging to person deixis. It is accompanied by thirty hundred and seven (307) words as deixis for the first person, one hundred and three seven (137) words as deixis for the second person and one hundred and six (106) words as deixis for the third person.

\section{Data 1: from song lyrics "needy",16-19}

And I can be needy, way too damn needy

I can be needy, tell me how good it feels to be needed

I can be needy, so hard to please me

$I$ know it feels so good to be needed

The song lyrics above is represented by the song writer's utterance in song lyric needy from thank $u$, next album. The deictic word $I$ above in bold italic type is used to point to the singular first person pronouns. The deictic word $I$ in the song lyrics above refer to the singer (song writer) itself. It refers to the singer (song writer) who describe about needy.

\section{Data 2: from song lyric "make up", lines 1-4}

I like to fuck with you just to make up with you 'cause the way you be screamin' my name

Make me wanna make love to you

I might break up with you just to make up with you

The song lyrics above is represented by the song writer's utterance in the song lyrics make up from thank $u$, next album. The deictic word you is 
categorized as pronoun and it is used to point to the singular second person deixis as the addressee or someone who has the direct contact with the singer (song writer) in song lyrics. The deictic word you in the song lyrics above refers to the man she was with.

\subsection{Spatial Deixis}

Based on Cruse (2006:166), spatial deixis is a deictic word used to point to the speaker and the addressee's position or distance. The most basic spatial deixis here and there. They refer to 'place close to the speaker' and 'place not close to the speaker' respectively, but with some verbs of motion or movement they refer to movement either towards or away from the speaker or listener.

Table 3. Spatial Deixis in Ten Songs of Ariana Grande's thank u, next Album

\begin{tabular}{|c|c|c|c|c|c|}
\hline \multirow[t]{2}{*}{ No } & \multirow[t]{2}{*}{ Song Title } & \multicolumn{4}{|c|}{ Spatial or Place Deictic Words } \\
\hline & & $\begin{array}{l}\text { Proximal } \\
\text { Term }\end{array}$ & Distal Term & $\begin{array}{l}\text { Motion or } \\
\text { Location }\end{array}$ & Specific \\
\hline 1 & Imagine & - & - & Let's Go, Go & \\
\hline 2 & Needy & This & - & Go Ahead & \\
\hline 3 & NASA & - & There & Leave & \\
\hline 4 & Bloodline & This & That & Leave, Go & \\
\hline 5 & fake smile & - & Far & Leave & \\
\hline 6 & bad idea & - & - & Come & \\
\hline 7 & make up & - & That & - & \\
\hline 8 & Ghostin & This, Here & That & Leaves, Comes & \\
\hline 9 & in my head & This, Here & There & Leave & \\
\hline 10 & 7 rings & - & - & - & \\
\hline 11 & thank $\mathrm{u}$, next & - & - & - & \\
\hline 12 & $\begin{array}{l}\text { break up with } \\
\text { your } \\
\text { girlfriend, i'm } \\
\text { bored }\end{array}$ & Here & That, There & - & \\
\hline
\end{tabular}

Spatial deixis can be seen from the above table and three terms of spatial deixis occur. This study found thirty two (32) deictic words belonging to spatial deixis, followed by nine (9) deictic words as spatial deixis' proximal term, ten (10) deictic words as spatial deixis' distal term, and thirteen (13) deictic words as spatial deixis' motion or specific location. 


\section{Data 3: from song lyric "break up with your girlfriend, i'm bored", lines} $\underline{1-4}$

Then I realize she's right there

And I'm at home like, "damn, this aint't fair"

Break up with your girlfriend

Yeah, yeah, 'cause I'm bored

The italic bold deictic word there indicates the location of the speaker or the song writer who utters the utterance in the lyric above. There indicates the location at a distance from the singer or song writer in the lyrics is located. It is known as a distal word because it shows the location not close to the speaker. In the song lyrics above, the deictic word there refers to a location not close to the singer (song writer) and refers about the singer which wants her crush become her mine, because the singer jealous with the woman he was with, and she felt it was unfair to see her in there with her crush.

\subsection{Temporal Deixis}

The time of the speech occurrence is referred to as temporal deixis or temporal deictic word (Cruse, 2006: 179; 2006: 321). This study found and classified the twelve (12) songs that illustrate temporal deixis or time deixis in each song from Ariana Grande's thank $u$, next album.

Table 4. Temporal Deixis in Twelve Songs of Ariana Grande's thank u, next

Album

\begin{tabular}{|c|c|c|c|}
\hline \multirow[t]{2}{*}{ No } & \multirow{2}{*}{$\begin{array}{l}\text { Song } \\
\text { Title }\end{array}$} & \multicolumn{2}{|c|}{ Temporal or Time Deictic Words } \\
\hline & & $\begin{array}{l}\text { Pure deictic word } \\
\text { and Specific time }\end{array}$ & Verb Tense \\
\hline 1 & Imagine & $\begin{array}{l}\text { All night, Until } \\
\text { noon }\end{array}$ & Thought, Would be, Knew, Were \\
\hline 2 & Needy & Lately & $\begin{array}{l}\text { Been, Messed Up, Dressed Up, Got, } \\
\text { Needed, }\end{array}$ \\
\hline 3 & NASA & Tonight, The night & Would, Pulling \\
\hline 4 & Bloodline & Next day & $\begin{array}{l}\text { Find, Trying, Feeling, Have to, Have a } \\
\text { good time, are you down, Got, Would, } \\
\text { you want }\end{array}$ \\
\hline 5 & $\begin{array}{l}\text { fake } \\
\text { smile }\end{array}$ & $\begin{array}{l}\text { Another night, } \\
\text { Now, Next Day, }\end{array}$ & Been through, I done, Mad, Crossed \\
\hline 6 & bad idea & Lately, Now & Been Worried, Would, Find, Should \\
\hline 7 & make up & The Day, All day, & Might, Mad, Looking \\
\hline
\end{tabular}




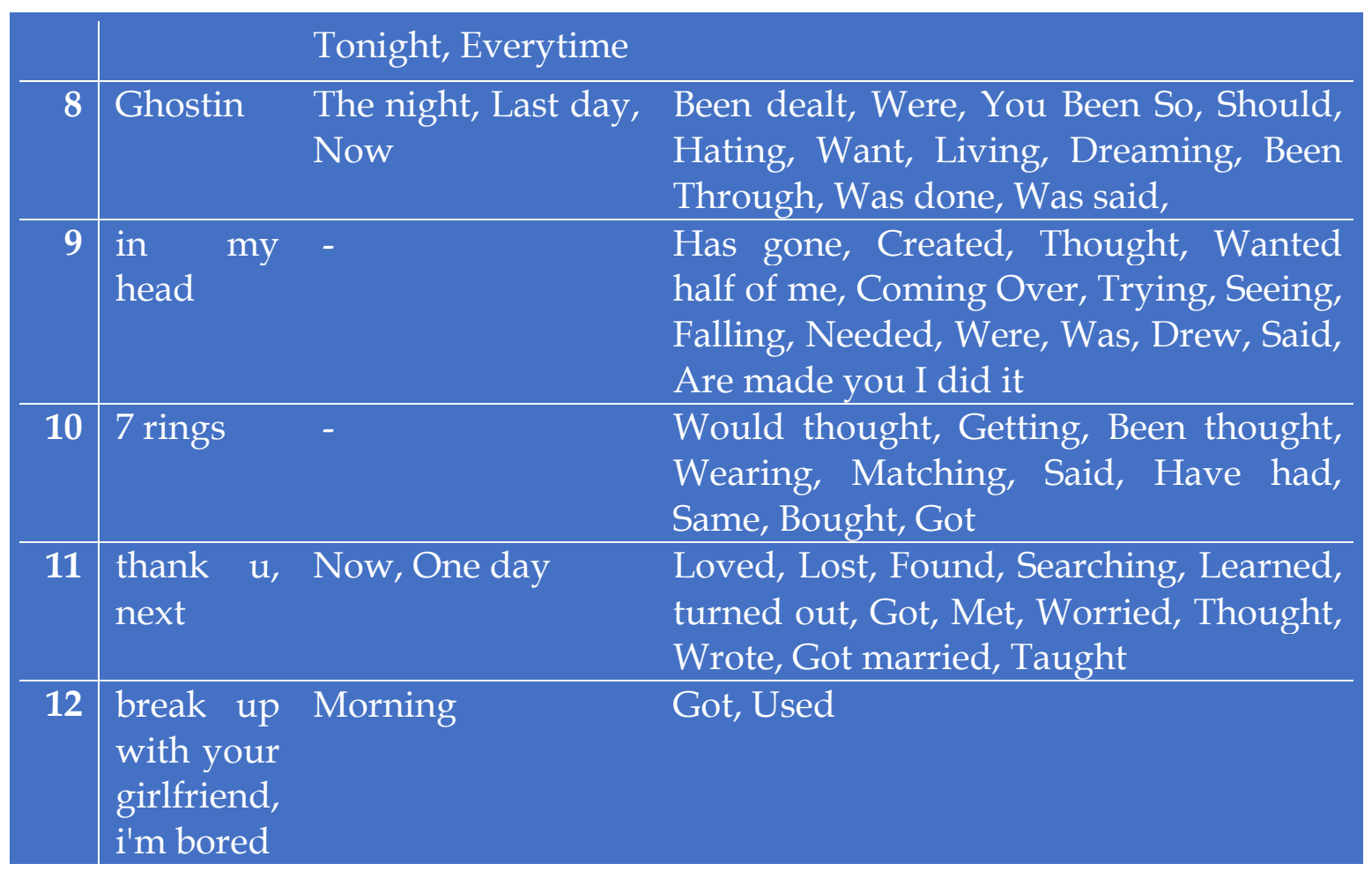

The temporal deictic words can be categorized from the table above into two terms of deictic words, such as pure and specific location of deictic words and verb tense as well. Then, it can be seen that all song lyrics from Ariana Grande's thank $u$, next album contain temporal deixis. This study finds one hundred nine (109) deictic words that belong to temporal deixis, consisting of twenty one (21) pure/specific deictic word deictic words and eighty eight (88) verb tense deictic words.

\section{Data 4: from song lyric "thank you next", lines 10-14}

One taught me patience

And one taught me pain

Now, I'm so amazing

Say I've loved and I've lost

But that's not what I see

The song lyrics above, the italic bold deictic word now is refers to the temporal deixis as pure temporal deictic word that indicate the timing of an event to the time of speaking. It is categorized as the second type of three major terms of deictic word axis which is at the time of utterance. The deictic word now in this lyric refers to the singer (song writer) already move on from the man she was with and at the moment she show that she already be better version of her own self. 


\subsection{Social Deixis}

Social Deixis refers to the relative social status and familiarity of the speaker and the listener (Cruse, 2006: 166). From eight (8) songs that signify the occurrence of social deixis. This research used the table to provide clear details on nineteen (19) songs in the song lyrics using social deixis.

Table 5. Social Deixis in Eight Songs of Ariana Grande's thank u, next

Album

\begin{tabular}{c|ll} 
No & \multicolumn{1}{c}{ Song Title } & \multicolumn{1}{c}{ Social Deictic Word } \\
\hline 1 & Imagine & Baby \\
\hline 2 & Needy & - \\
\hline 3 & NASA & - \\
\hline 4 & Bloodline & Baby \\
\hline 5 & fake smile & Baby \\
\hline 6 & bad idea & Baby \\
\hline 7 & make up & - \\
\hline $\mathbf{8}$ & Ghostin & Baby \\
\hline 9 & in my head & - \\
\hline 10 & 7 rings & Baby, My friends \\
\hline 11 & thank u, next & My friend, My Ex, My mama, \\
& & My dad \\
\hline 12 & break up with your girlfriend, i'm & Baby, Girlfriend \\
& bored &
\end{tabular}

\section{Data 5: from song lyric "imagine", lines 22-26}

Thought that it would be you

Tell me your secrets, all of the creep shit

That's how I know it's true

Baby, direct it, name in the credits

Like the movies do

The song lyrics above, it can be seen the deictic word baby is indicated the term of social deixis because the addressee has intimacy relative to the singer (song writer). The word $b a b y$ is refers to the singer or song writer's boyfriends who is really special for her. The deictic word $\boldsymbol{b a b y}$ in the song lyrics above refers to the singer (song writer) and she want her boyfriend to tells about his secret to know the truth.

\subsection{Discourse Deixis}

Discourse deictic terms refer to points that refer to the use of this to refer to the components of the future discourse and that to refer to 
components of the past discourse. It can connect earlier discourse points to parts of later discourse (Cruse, 2006:51).

Table 6. Discourse Deixis in Eight Songs of Ariana Grande's thank u, next Album

\begin{tabular}{r|ll} 
No & \multicolumn{1}{c}{ Song Title } & Discourse Deictic Word \\
\hline $\mathbf{1}$ & Imagine & This \\
\hline $\mathbf{2}$ & Needy & That \\
\hline $\mathbf{3}$ & NASA & This \\
\hline $\mathbf{4}$ & Bloodline & That \\
\hline $\mathbf{5}$ & fake smile & - \\
\hline $\mathbf{6}$ & bad idea & This \\
\hline $\mathbf{7}$ & make up & That \\
\hline $\mathbf{8}$ & Ghostin & That \\
\hline $\mathbf{9}$ & in my head & That \\
\hline $\mathbf{1 0}$ & 7 rings & - \\
\hline $\mathbf{1 1}$ & thank u, next & - \\
\hline $\mathbf{1 2}$ & break up with your girlfriend, i'm & - \\
& bored &
\end{tabular}

It can be seen from the table above that discourse deixis exists in eight (8) songs from the thank $u$, next album by Ariana Grande. Seven (7) deictic terms belonging to the discourse deixis were found in this research

\section{Data 6: from song lyric "thank $u$, next", lines34-37}

She taught me love (love)

She taught me patience (patience)

She handles pain (pain)

That amazing (yeah, she's amazing)

The use of italic bold deictic word that in the lyric above is indicated the discourse deixis because the singer (song writer) described the feeling that she feels and the feeling that she feel only the singer (song writer) knows about that feeling. The deictic word that in here refers that the singer (song writer) feel better and can not feel pain again after broke up

\section{CONCLUSION}

The conclusion of this research is that all types of deixis which are person deixis, spatial deixis, temporal deixis, social deixis and discourse deixis occurs in the thank $u$, next album of Ariana Grande. The dominant used in these song lyrics is person deixis of all types of deixis with 550 
data discovered and followed by temporal deixis with 109 data discovered, then discourse deixis with 7 data discovered, spatial deixis with 32 data discovered and the last social deixis with 19 data discovered. The total data collected in this analysis is 717 .

\section{REFERENCES}

Cruse, A. (2000). Meaning in Language: An Introduction to Semantics and Pragmatics. New York: Oxford University Press.

Cruse, A. (2006). A Glosarry of Semantics and Pragmatics. Edinburgh: Edinburgh University Press.

Leech, Geoffrey. 1983. Principles of Pragmatics. Harmondsworth: Penguin Levinson, S. C. (1983). Pragmatics. New York: Oxford University Press. Yule, G. (1996). Pragmatics. Oxford: Oxford University Press 